\title{
Reappraising David Livingstone's The Geographical Tradition: A quarter of a century on
}

\author{
Mark Boyle $^{1}$ (D) | Tim Hall ${ }^{2}$ (D) | James D. Sidaway ${ }^{3}$
}

\author{
${ }^{1}$ Heseltine Institute for Public Policy, \\ Practice and Place, University of \\ Liverpool, Liverpool, UK \\ ${ }^{2}$ Department of Archaeology, \\ Anthropology and Geography, University \\ of Winchester, Winchester, UK \\ ${ }^{3}$ Department of Geography, National \\ University of Singapore, Singapore

\section{Correspondence} \\ Mark Boyle \\ Email: mark.boyle@liverpool.ac.uk \\ [Correction added on 15 April 2019 after \\ first publication: the reference list has \\ been updated and corresponding citations \\ added in this version.]
}

The quarter of a century since the publication of David Livingstone's The Geographical Tradition in 1992 provides an apt moment to reflect on the book's theses, lacunae, and legacies, and to take stock of the ways in which its provocations and reception might instruct the wider project of rendering the discipline's history. In framing this themed intervention, we engage the assertion that contextualisers need contextualising; there exists scope to heighten awareness of the location within time, space and culture from which contextualist historiographies of geography are written. We call attention to the meaning and implications of the particular and situated contextualist methodology mobilised and executed in The Geographical Tradition.

\section{KEYW OR D S}

classics, David Livingston, empire, Geographical Tradition, historiography, science

\section{1 | INTRODUCTION}

Framed by a striking cover-image of a painting by Dutch artist Johannes Vermeer (that also appeared on the cover of Norton, 1984) depicting a 17th-century geographer at work (titled The Geographer and signed and dated 1699, see Figure 1), David Livingstone's (1992) The Geographical Tradition: Episodes in the History of a Contested Enterprise quickly became a milestone, shifting the ground in scholarship on the history of geography.

Livingstone detected two critical flaws in existing historiographical accounts: "presentism" or interpreting past geographical ideas by the (scientific, moral, and aesthetic) standards of today, and "internalism" or construing the evolution of the discipline in terms of interior drivers of change (scholarly fields, their champions, spats, alignments, and plays). Refusing to label and police the boundaries of his alternative approach too strictly, he invoked the simple yet powerful idea of "situated messiness": all academic endeavour, including the act of creating, disseminating, and ingesting geographical knowledge, is best thought of as a situated social practice inextricably embroiled in the wider social, economic, political, and intellectual dramas of the day. In particular, the history of geography could not be told apart from a history of European capitalism, empire, racism, and science. There followed a polymathic reading of over 500 years of "episodes in the history of a contested enterprise," incorporating, among other things, geography's entanglements in: the age of reconnaissance; the scientific revolution and its alter ego, alchemy; the European enlightenment and age of reason; the pre-Darwinian expedition tradition; Darwinism and the institutional politics of the 19th-century European academy; European imperial expansion, colonisation, and scientific racism; shifting understandings of the nature/culture nexus; and technological change and the quantitative revolution.

Amongst the blurb endorsements, Peter R. Gould (1932-2000) wrote that this is the "book that will become the core of all courses and seminars in the history and philosophy of our field." And given the status it quickly acquired, it is unsurprising that The Geographical Tradition has inspired periodic re-reading and reappraisal as well as celebration. Werrity and Reid 


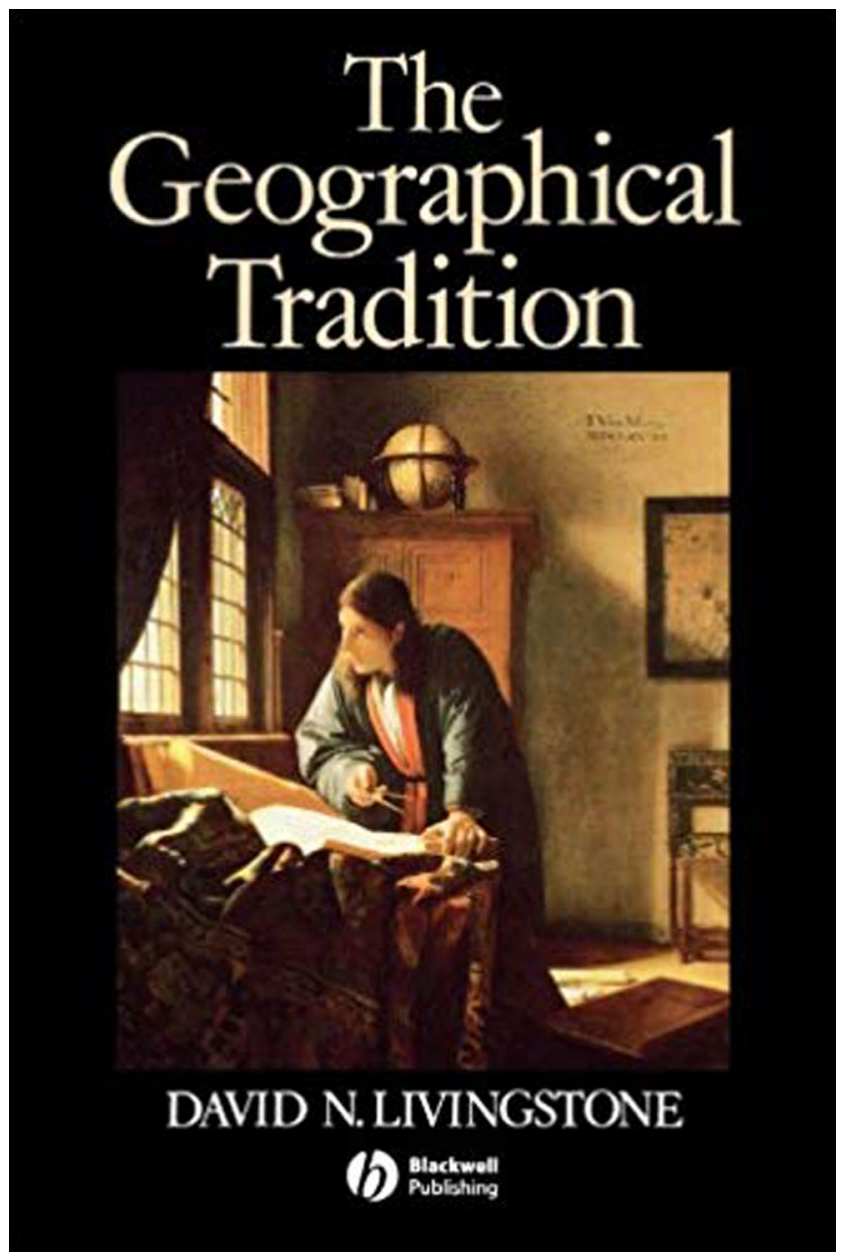

F I G U RE 1 Johannes Vermeer, “The Geographer” 1669. Städel Musuem, Frankfurt am Main.

Source: Photo @ Städel Musuem-ARTOTHEK as reproduced on the front-cover of The Geographical Tradition [Colour figure can be viewed at wileyonlinelibrary.com]

described it as a book that could "send one running down the corridor doing cartwheels" (1995, p. 196). For Spedding, "The history of Geography often, thought of as the poor relation to "proper' contemporary research, received a major boost" (2008, p. 160). Mayhew observed that responses "came from scholars across the spectrum of human geography, rather than being restricted to a coterie of historians of Geography" (Mayhew et al., 2004, p. 228). The Geographical Tradition has shaped subsequent histories of the discipline, including later editions of one that first appeared 13 years before it was published (Johnston \& Sidaway, 2016). Without prejudice to the rich diversity of scholarly reflection it has provoked, other noteworthy engagements include: David Hooson's book review in Yearbook of the Association of Pacific Coast Geographers, Gillian Rose's book review in History of the Human Sciences, and Gregory Good's book review in ISIS: A Journal of the History of Science Society (all 1993); Driver et al.'s (1995) edited "open-ended discussion of the possibilities and limits of thinking about [and transforming] 'traditions' of geographical enquiry" (p. 403) published in Transactions of the Institute of British Geographers; a set of reviews and a response (Withers et al., 1996) published in Ecumene (now Cultural Geographies); an interview with David Livingstone conducted by Hoyler et al. (2002) in Heidelberg following his 2001 Hettner Lecture; and Mayhew's (2015) reflections on canonical texts in human geography published in the Journal of Historical Geography.

Prior reviews and several of the essays that follow signal the significance of the fact that The Geographical Tradition arrived at a moment when, in the wake of all kinds of turbulence, geography was again having to struggle for identity, coherence, and sometimes existence. Such struggles in the past, as in the post-war elimination of geography at Harvard (Smith, 1987), arguably fed into the discipline's drive to re-make itself as scientific. Later struggles (from the 1990s onwards), centred often around managerial efforts to rebrand and rename departments and schools of geography, wrestled with questions about geography's purpose, marketability and focus, and spurred defensive turns to relevant or applied research putatively high in impact (Castree, 2011; Frazier \& Wikle, 2017; Hall et al., 2015; Lahiri-Dutt, 2018). In these contexts, Livingstone's rich historiographical account has surely provided useful reassurance to many geographers. The 
book was both scholarly and yet accessible enough to garner wide readerships. It could be read as an advanced-level textbook (a mark of its origins, as Livingstone reveals below) and as a powerful research monograph: a rare combination (Sidaway \& Hall, 2018). In both capacities it profiled and itself displayed scholarly intensity and intellectual gravitas in/for Geography; a path to legitimacy and influence. The Geographical Tradition has existed as a point of reference in a sea of change. Moreover, Livingstone's celebration of diversity, fluidity, plurality and entangled traditions - "messiness" - gestures in an inclusive way to the scholarly merits of multiple geographical traditions.

We use the occasion of the book's 25th anniversary to reflect once more on its virtues, vices, and ongoing significances. Certainly, this anniversary begets curiosity about the longevity and resilience of the text and its capacity to remain vital. But our purpose is to do more than celebrate a birthday. While not alone, The Geographical Tradition proved key in advancing the case for historicising, relativising, and provincialising geographical philosophies and practices - indeed something called Geography period - and giving scholarly and eloquent expression to the kinds of archival methods, analytic instruments, and modalities of narration such a project might demand. Of course, no single book can bear the weight of responsibility for a historiographical method and no historiographical method ought to be held accountable on the basis of a single book. However, it is our supposition that the quarter-century since The Geographical Tradition was published provides an apt moment to reflect not only once again on the book's core theses, lacunae, and legacies, but also to take stock of the ways in which its provocations and reception might instruct the wider project of rendering the discipline's history contextually.

The papers that follow began life in London at a panel session of the 2017 annual conference of the Royal Geographical Society (with the Institute of British Geographers). We asked panellists to consider earlier engagements with the book, to revisit as well as to bring updated and perhaps even some fresh perspectives to bear. The conference theme in 2017 was "Decolonising geographical knowledges: opening geography out to the world," a theme that elicited an early response, probing "why this pursuit of critical consciousness via a decolonial approach could do more harm than good, in a discipline that may not be ready to, or even capable of, responding to the challenge of decolonisation" (Esson et al., 2017, p. 384). In setting the scene we were also mindful of feminist and queer theory confrontations with human geography's masculinist, metropolitan and imperial theoretical and methodological inheritances. We were also alert to the ongoing reconfigurations of geography in and through fiscal crisis, post-crash neoliberalism redux, a fourth (cyber-physical, AI, and digital) industrial revolution (succeeding, steam, electric and electronic ones) and attendant socio-spatial shifts; climate change, accompanied by reworked environmental determinisms, as Livingstone and the late Doreen Massey (2004) noted in a wide-ranging discussion; post-imperial migration corridors, right-wing populism, historical and contemporary imaginaries of "race" (on which The Geographical Tradition provided a detailed exposé of geography's complicity) and the reworking of and challenges to racism in geography; and further "quantitative revolutions" in geographical science wrought by big data, geocomputation, and cartographic innovations (geo-visualisation).

In framing the set that follows, we also want to re-awaken the distinction between "analytical reason" and "dialectical reason." The former, a remnant of the "long 18th-century" European Enlightenment construes reason as positivist and independent of any particular rational system; the latter, rooted in historical materialism holds reason to be historically embedded, relative to a socially constructed system of logic and therefore constituent. Contextualist framings of the history of Geography have helped scholars of the discipline to better understand that all reason is produced within history; lacking in self-understanding, analytical reason is simply a form of dialectical reason that is unconscious of its own historicity. We better appreciate the significance of placing geographical traditions: how these traditions emerge in time and space and bear the imprint of the worlds in which they emerge, dwell, flourish, and wither. But by extension, constituent reason can only be understood historically: all acts of contextualising themselves need contextualising if their analytic rationalities, cultural frames, and politics are to be fully grasped. While widely acknowledged, perhaps this observation warrants more intensive interrogation than has been the case thus far.

In this introduction, and with respect to The Geographical Tradition, we call attention to the impact of the proximity of historians in time, space, and culture to the geographical traditions about which they write, especially as this proximity bears on their capacity to apprehend particular traditions contextually, the choices they make concerning which voices best articulate traditions and therefore whose biographies merit contextualisation, and the ends to which they dedicate their endeavours to locate, situate, and place traditions.

The Geographical Tradition undoubtedly broke new ground in its relentless scrutiny of the reciprocal constitution of text and context and its sustained contextualist interrogation of Geography, geography and geographers. For Withers (2001, p. 4) a key to The Geographical Tradition was Livingstone's "insistence that we must situate geography historically and geographically." Still, below Van Meeteren (2019) contends that Livingstone applied his contextualist methodology with varying degrees of intensity between chapters and in particular only lightly in his chapter on 
Geography's "spatial science" tradition. Falling prey itself from "internalism," this chapter, he asserts, would have benefited from a more thoroughgoing historicisation and politicisation. It is at once glib but also accurate to assert that particular challenges attend to the production of histories of the present. Certainly, Van Meeteren's critique is especially significant in the light of the urgent need to place geography's most recent turn to big data, geocomputation, and spatial statistics, within the context of new waves of science predicated on data-intensive scientific discovery and the rise of data-driven economies, artificial intelligence, machine learning, and smart and automated systems. But his intervention also begets a larger question: do there exist historical, analytical, or political reasons for supposing that some episodes in the history of Geography are more difficult to contextualise than others? Or to put it another way, do particular subject positions make it harder to provincialise certain geographical traditions?

The Geographical Tradition is littered with allusions to its inescapable partiality and bias: by explicit self-admission this was Livingstone's constitution rather than reconstruction of the history of Geography; his episodes and narrative thereof. It is unfair and undoubtedly frustrating for Livingstone then when critics expose the partisanship of the book as a significant shortcoming, succumbing themselves on occasions as he notes both elsewhere and below (Livingstone, 2019) to presentist readings of the text. Still, it is worth recalling Anne Godlewska's observation in Geography Unbound: "Taking a history of ideas approach to the concept of 'tradition' as does Livingstone - following a particular line of descent - de-emphasizes the exclusions, the contestations, the lulls, the gaps, and the collapses in the history of Geography" (1999, p. 315). Contextualist approaches need to turn methodological principles such as "situated messiness" more forcibly back against themselves and reflect on the ways in which they too are conjuring historiographies of the discipline within history. And so we are forced to confront the limits, omissions, and exclusions inherent in the contextual reading offered in The Geographical Tradition. Below, each of Craggs (2019), Ferretti (2019), Maddrell (2019) (who builds on a key feminist critique of The Geographical Tradition by Rose, 1995, that also appeared in Transactions) and Van Meeteren (2019) identify absent figures, texts, and voices - adding to those identified in previous engagements - which in their view skew the narrative developed in the book, a wider issue for histories of geography, that is perhaps more often reiterated as a problem than resolved (Keighren, 2018). Similarly, Scott Kirsch (in Keighren et al., 2017, p. 255) notes how The Geographical Tradition had "served to open the subject" and had been "personally radicalizing in some ways," but how "today, to a more diverse and international graduate student population, and with situated histories of science becoming more or less mainstream, The Geographical Tradition seems helplessly Euro-centric." Indeed. Engaging the book, one of us angrily asked "what still makes ethnically cleansed histories of geography possible?" (Sidaway, 1997, p. 77).

To what other ends should contextualist histories of geography be mobilised? Or as Clive Barnett (1995) puts it more bluntly, why should we awaken geography's dead? As the promises of modernity ebb to exhaustion, the West stumbles from one crisis to another and end of history arguments seem ever more incredulous, the possibility of progress in human geography too attracts ever-greater suspicion. Livingstone (2019) himself detects an unresolved tension between Whiggism and relativism in historiographical accounts. Of course, Barnett's question too can only be answered within history. Histories of geography are energised by time- and place-specific cultures of time consciousness and futurity (Hayes, 2018). Perhaps an advance of sorts may be found in some postcolonial, feminist, and queer ontologies of time; here, while the meaning of history is conceived variously, the idea that history is simply teleology becoming conscious of itself is contested by the claim that history is better considered as claims of progress becoming conscious of their geographies. "Geographising Geography," to use Livingstone's own phrase, indeed has an ongoing critical role. Only by understanding our biography will we understand the exceptional peculiarity of our lens and the potentialities and compromises which this lens affords and furnishes. And in this, in disentangling the making of some of those geographies, The Geographical Tradition is likely to continue to instruct and provoke.

\section{ACKNOWLEDGEMENTS}

While the usual disclaimers apply, we thank Simon Naylor and the anonymous referees for their encouragement and comments on earlier drafts of this introduction and the set that follows. Ron Johnston and Henry Yeung also helpfully commented on an earlier draft. We are grateful to authors for their willingness to convert comments from what began as a conference panel session into the written texts here. We thank the History and Philosophy of Geography Research Group and the Race, Culture and Equality Working Group (both of the Royal Geographical Society, with the Institute of British Geographers) for sponsoring the panel at the 2017 Annual Conference of the RGS-IBG. Finally, we dedicate the set to the memory of John Davey (1945-2017) - the far-sighted publisher who guided The Geographical Tradition and many other noteworthy publications into print (Haggett, 2018). 


\section{ORCID}

Mark Boyle (D) https://orcid.org/0000-0002-9882-3907

Tim Hall (D) https://orcid.org/0000-0002-2160-9152

James D. Sidaway (iD https://orcid.org/0000-0001-6169-3566

\section{REFERENCES}

Barnett, C. (1995). Awakening the dead? Who needs the history of geography? Transactions of the Institute of British Geographers, 20, 417419. https://doi.org/10.2307/622971

Castree, N. (2011). The future of geography in English universities. The Geographical Journal, 177, 294-299. https://doi.org/10.1111/j.1475-4959. 2011.00412.x

Craggs, R. (2019). Decolonising The Geographical Tradition. Transactions of the Institute of British Geographers, 43, 444-446. https://doi.org/ $10.1111 / \operatorname{tran} .12295$

Driver, F. (1995). Introduction: Geographical traditions: Rethinking the history of geography. Transactions of the Institute of British Geographers, 20, 403-404. https://doi.org/10.1234/12345678

Esson, J., Noxolo, P., Baxter, R., Daley, P., \& Byron, M. (2017). The 2017 RGS-IBG chair's theme: Decolonising geographical knowledges, or reproducing coloniality? Area, 49, 384-388. https://doi.org/10.1111/area.12371

Ferretti, F. (2019). The Geographical Tradition on the move: The transnational travels of a classic. Transactions of the Institute of British Geographers, 43, 447-449. https://doi.org/10.1111/tran.12296

Frazier, A. E., \& Wikle, T. A. (2017). Renaming and rebranding within U.S. and Canadian Geography departments, 1990-2014. The Professional Geographer, 69, 12-21. https://doi.org/10.1080/00330124.2015.1135404

Godlewska, A. M. C. (1999). Geography unbound: French geographic Science from Cassini to Humboldt. Chicago, IL: University of Chicago Press. https://doi.org/10.7208/chicago/9780226300535.001.0001

Good, G. A. (1993). The geographical tradition: Episodes in the history of a contested enterprise by David N Livingstone. ISIS: A Journal of the History of Science Society, 84, 778-779. https://doi.org/10.1086/356656

Haggett, P. (2018). John Davey (1945-2017) and the origins of the 'Progress in Geography' journals. Progress in Human Geography, 42, 327329. https://doi.org/10.1177/0309132518773174

Hall, T., Toms, P., McGuinness, M., Parker, C., \& Roberts, N. (2015). Where's the Geography department? The changing administrative place of Geography in UK higher education. Area, 47, 56-64. https://doi.org/10.1111/area.12154

Hayes, E. (2018). Geographical light: The magic lantern, the reform of the Royal Geographical Society and the professionalization of geography c. 1885-1894. Journal of Historical Geography, 62, 24-36. https://doi.org/10.1016/j.jhg.2018.04.003

Hooson, D. (1993). The geographical tradition by David Livingstone (review). Yearbook of the Association of Pacific Coast Geographers, 55, 166-167. https://doi.org/10.1353/pcg.1993.0010

Hoyler, M., Freytag, T., \& Jons, H. (Eds) (2002). Geographical traditions, science studies, and biography: A conversation with David N. Livingstone. In D. N. Livingstone (Ed), Science, space and hermeneutics: Hettner Lecture 2001 [with David N. Livingstone] (pp. 77-98). Heidelberg, Germany: Department of Geography, University of Heidelberg.

Johnston, R., \& Sidaway, J. D. (2016). Geography and geographers: Anglo-American human geography since 1945 (7th ed.). London, UK: Routledge.

Keighren, I. M. (2018). History and philosophy of geography III: The haunted, the reviled and plural. Progress in Human Geography, Advance online publication. https://doi.org/10.1177/0309132518818725

Keighren, I. M., Crampton, J. W., Ginn, F., Kirsch, S., Kobayashi, A., Naylor, S. N., \& Seemann, J. (2017). Teaching the history of geography: Current challenges and future directions. Progress in Human Geography, 41, 245-262. https://doi.org/10.1177/0309132515575940

Lahiri-Dutt, K. (2018). "Academic war" over geography? Death of human geography at the Australian National University. Antipode, Advance online publication. https://doi.org/10.1111/anti.12496

Livingstone, D. N. (1992). The geographical tradition: Episodes in the history of a contested enterprise. Chichester, UK: John Wiley and Sons.

Livingstone, D., \& Massey, D. (2004). Geography and geographical thought. In R. Lee, N. Castree, R. Kitchin, V. Lawson, A. Paasi, C. Philo, S. Radcliffe, S. M. Roberts \& C. W. J. Withers (Eds.) The Sage handbook of human Geography (pp. 729-742). London, UK: Sage. A video of the conversation is available at: http://bcove.me/siljk2yb (last accessed 10 March 2019)

Livingstone, D. (2019). The Geographical Tradition and the challenges of geography geographised. Transactions of the Institute of British Geographers, 43, 458-462. https://doi.org/10.1111/tran.12299

Maddrell, A. (2019). Reappraising david livingstone's The Geographical Tradition from complex locations: More-than-contextual historiographies. Transactions of the Institute of British Geographers, 43, 450-453. https://doi.org/10.1111/tran.12297

Mayhew, R. J. (2015). Enlightening choices: A century of Anglophone canons of the geographical tradition. Journal of Historical Geography, 49, 9-20. https://doi.org/10.1016/j.jhg.2015.04.016

Mayhew, R. J., Driver, F., \& Livingstone, D. N. (2004). Classics in human geography (Livingstone, D. N. 1992: The geographical tradition: Episodes in the history of a contested enterprise). Progress in Human Geography, 28, 227-234. https://doi.org/10.1191/0309132504ph482xx

Norton, W. (1984). Historical analysis in geography. London, UK and New York, NY: Longman. 
Rose, G. (1993). Reviews: David N Livingstone The geographical tradition: Episodes in the history of a contested enterprise. History of the Human Sciences, 6, 125-129. https://doi.org/10.1177/095269519300600410

Rose, G. (1995). Tradition and paternity: Same difference? Transactions of the Institute of British Geographers, 20, 414-416. https://doi.org/10. $2307 / 622970$

Sidaway, J. D. (1997). The (re)making of the western 'geographical tradition': Some missing links. Area, 29, 72-80. https://doi.org/10.1111/j. 1475-4762.1997.tb00008.x

Sidaway, J. D., \& Hall, T. (2018). Geography textbooks, pedagogy and disciplinary traditions. Area, 50, 34-42. https://doi.org/10.1111/area. 12397

Smith, N. (1987). "Academic war over the field of geography": The elimination of geography at Harvard, 1947-1951. Annals of the Association of American Geographers, 77, 155-172. https://doi.org/10.1111/j.1467-8306.1987.tb00151.x

Spedding, N. (2008). The geographical tradition (1992): David Livingstone. In P. Hubbard, R. Kitchin \& G. Valentine (Eds.), Key texts in human geography (pp. 153-161). London, UK: Sage. https://doi.org/10.4135/9781446213742

Van Meeteren, M. (2019). Statistics do sweat: Situated messiness and spatial science. Transactions of the Institute of British Geographers, 43, 454-457. https://doi.org/10.1111/tran.12298

Werritty, A., \& Reid, L. (1995). Debating the geographical tradition. Scottish Geographical Magazine, 111, 196-197. https://doi.org/10.1080/ 00369229518736968

Withers, C. W. J. (2001). Geography, science and national identity: Scotland since 1520. Cambirdge, UK: Cambridge University Press.

Withers, C. W. J., Camerini, J., Heffernan, M., \& Livingstone, D. (1996). Conversations in review. Ecumene, 3, 351-360.

How to cite this article: Boyle M, Hall T, Sidaway JD. Reappraising David Livingstone's The Geographical

Tradition: A quarter of a century on. Trans Inst Br Geogr. 2019;44:438-443. https://doi.org/10.1111/tran.12294 